\title{
Using Computational Fluid-Dynamics (CFD) for the evaluation of beer pasteurization: effect of orientation of cans
}

\author{
Utilização de fluidodinâmica computacional (CFD) na avaliação da \\ pasteurização de cervejas: efeito da orientação da lata
}

Pedro Esteves Duarte AUGUSTO ${ }^{1,2 *}$, Talita Ferramola PINHEIRO $^{1,2}$, Marcelo CRISTIANINI ${ }^{1}$

\begin{abstract}
In-package pasteurization is the most used method for beer microbiological stabilization. The search for safer and better quality food has created a need to better understand the processes involved in producing it. However, little is known about the temperature and velocity profiles during the thermal processes of liquid foods in commercial packaging, which results in over-dimensioned processes to guarantee safety, decreasing the sensorial and nutritional characteristics of the product and increasing process costs. Simulations using Computational Fluid-Dynamics (CFD) have been used by various authors to evaluate those processes. The objective of the present paper was to evaluate the effect of packaging orientation in the pasteurization of beer in a commercial aluminum can using CFD. A heating process was simulated at $60{ }^{\circ} \mathrm{C}$ up to 15 PUs (a conventional beer process, in which 1 Pasteurization Unit (PU) is equivalent to 1 minute at $60{ }^{\circ} \mathrm{C}$ ). The temperature profile and convection current velocity along the process and the variation of the PUs were evaluated in relation to time considering the cans in the conventional, inverted, and horizontal positions. The temperature and velocity profiles were similar to those presented in the literature. The package position did not result in process improvement.

Keywords: mathematic modeling; Computational Fluid-Dynamics (CFD); thermal treatment; pasteurization; processes optimization; beer.
\end{abstract}

\section{Resumo}

A pasteurização dentro da embalagem é o método mais usado para a estabilização microbiológica de cervejas. A crescente busca por alimentos mais seguros e de melhor qualidade cria a necessidade de melhor entendimento dos processos envolvidos na sua produção. Entretanto, pouco se conhece sobre os perfis de temperatura e velocidade durante o tratamento térmico de alimentos líquidos em embalagens comerciais, muitas vezes resultando em processos superdimensionados como garantia de segurança, porém comprometendo características sensoriais e nutricionais do produto e custos do processo. Simulações por fluidodinâmica computacional (CFD) têm sido usadas por vários autores na avaliação desses processos. O presente trabalho teve como objetivo avaliar o efeito da orientação da embalagem na pasteurização de cerveja em uma lata comercial de alumínio por meio de CFD. Simulou-se aquecimento a $60^{\circ} \mathrm{C}$ até $15 \mathrm{UPs}$ (processo convencional de pasteurização em cervejas, em que 1 unidade de pasteurização (UP) equivale a 1 minuto a $60^{\circ} \mathrm{C}$ ). Avaliou-se o perfil de temperatura e velocidade das correntes de convecção ao longo do processo e a variação das UPs em relação ao tempo, considerando as latas na posição convencional, invertida e horizontal. Os perfis de temperatura e velocidade mostraram-se adequados ao esperado segundo dados da literatura. Ao contrário da esterilização de alimentos líquidos consistentes em latas cônicas, a orientação da embalagem não resultou em melhoria no processo. Palavras-chave: modelamento matemático; fluidodinâmica computacional (CFD); tratamento térmico; pasteurização; otimização de processos; cerveja.

\section{Introduction}

The process of beer pasteurization guarantees stability of the product without refrigeration (BUZRUL, 2007; DILAY et al., 2006). Generally, it is carried out in pasteurization tunnels with various heating, retention, and cooling zones, in which heat transfer occurs through a water film formed by aspersion on the package (DILAY et al., 2006; HORN et al., 1997; BRANDON et al., 1984; BRANDON; HULING; STAACK, 1983; ENGELMAN; SANI, 1983; BRANDON; PELTON; STAACK, 1982). The process is dimensioned in "Pasteurization Units" (PU), in which $1 \mathrm{PU}$ is equivalent to 1 minute at $60{ }^{\circ} \mathrm{C}$, and it is carried out in levels from 5 to 15 PUs (BUZRUL, 2007; DILAY et al., 2006).
Even though other processes can be used, such as pasteurization in heat exchangers ("flash" pasteurization) (RIVEROL; NAPOLITANO, 2002; BLANPAIN-AVET; FILLAUDEAU; LALANDE, 1999), using membranes (FILLAUDEAU; CARRERE, 2002; BLANPAIN-AVET; FILLAUDEAU; LALANDE, 1999), carbon dioxide in dense phase (DAGAN; BALABAN, 2006), high pressure homogenization (TRIBST; FRANCHI; CRISTIANINI, 2008; FRANCHI, 2007), or hydrostatic high pressure (BUZRUL; ALPAS; BOZOGLU, 2005a, b) among others, pasteurization in cans and bottles is still a widely used method for beer stabilization (DAGAN; BALABAN, 2006; REVERON; BARREIRO; SANDOVAL, 2003).

\footnotetext{
Recebido para publicação em 9/10/2008

Aceito para publicação em 20/6/2009 (003879)

Department of Food Technology, School of Food Engineering, University of Campinas - UNICAMP, CP 6121, CEP 13083-862, Campinas - SP, Brazil,

E-mail: pedro@cotuca.unicamp.br

Technical School of Campinas, University of Campinas - UNICAMP, Campinas - SP, Brazil

${ }^{*}$ A quem a correspondência deve ser enviada
} 
Even though pasteurization of beers is a mild thermal process, the optimization of heat transfer during the process is desired to guarantee smaller sensorial alterations (BUZRUL, 2007; REVERON; BARREIRO; SANDOVAL, 2003) and energy costs (DILAY et al., 2006).

The characteristics of liquid flow inside the container during heating are a function of its geometry and even small alterations can result in differences in the process (BRANDON et al., 1984). However, little attention has been devoted on modifications in the thermal processing of liquid foods through changes in geometry or orientation of its packaging (VARMA; KANNAN, 2006, 2005). Kannan and Sandaka (2008) observed the need to understand better the heat transfer phenomenon associated to thermal treatments of liquid foods to improve the processes. According to Xia and Sun (2002), the use of mathematical modeling through Computational Fluid-Dynamics (CFD) in the food industry can help these evaluations and developments.

CFD is a numerical technique of solving equations which govern the fluid flow and heat transfer in a determined geometry. It consists of numerical and simultaneous resolution of the Navier-Stokes Transport Equations, which describe the conservation of mass, moment and energy, and state equations (NORTON; SUN, 2006; SCOTT; RICHARDSON, 1997).

Various authors have been using CFD as a tool to evaluate thermal processes of foods. The use of this technique allows for thermal process evaluation through isothermal and convective current velocity profiles, the localization of the cold spot or Slower Heating Zone (SHZ), and transformations in the foods such as the inactivation and destruction of microorganisms, enzymes, and nutrients.

The present paper had the objective to study the orientation of the packaging on the process of pasteurizing beers in aluminum cans, using CFD.

\section{Material and methods}

\subsection{Mathematical model}

Traditional $375 \mathrm{~mL}$ volume, $121 \mathrm{~mm}$ height and $62 \mathrm{~mm}$ diameter aluminum cans (Figure 1), which are used to market beer in Brazil were used in the the experiments.

Simulations were performed by CFD analysis, using the Ansys CFX 11.0 program (Ansys Inc., EUA), which is based on the Finite Volumes Analysis (FVA). The tri-dimensional model was obtained from the actual geometry of the packaging, obtained through the evaluation of its longitudinal section on millimeter squared paper, as used by Augusto, Santana and Cristianini (2008), Santana (2007), Pinho and Cristianini (2005) and Cristianini and Massaguer (2002). Due to the axial symmetry of the containers in the vertical orientation, only one quarter was considered in elaborating the model, which was generated by the revolution of the areas previously obtained (Figure 1); only a half of it was considered in the simulation of the can in the horizontal orientation due to the symmetry in the longitudinal plane (Figure 1).
The model was composed of two parts, product and headspace. Due to the small thickness of the packaging and high thermal conductivity of the aluminum, the thermal resistance of the cans was considered to be negligible (KUMAR; BHATTACHARYA; BLAYLOCK, 1990; GHANI et al., 1999a). According to Brandon et al. (1984), water can be used as a model in the evaluation of beer pasteurization. For this reason, pure water thermal properties were used to simulate the product, considering the can filled with $350 \mathrm{~mL}$, the standard volume in selling beers in the packaging in question. The headspace was considered as a conductive layer of saturated air, as described by Pinho and Cristianini (2005) and Varga, Oliveira and Oliveira (2000), with physical properties described by Pinho and Cristianini (2005).

The mesh was generated refining the fluid borders, a region with larger temperature and velocity gradient (KUMAR; DILBER, 2007), as used by many authors (KANNAN; SANDAKA, 2008; GHANI; FARID, 2006; VARMA; KANAN, 2006, 2005; FARID; GHANI, 2004; GHANI; FARID; CHEN, 2002a; GHANI et al., 1999a, 1999b; KUMAR; BHATTACHARYA, 1991; KUMAR; BHATTACHARYA; BLAYLOCK, 1990; DATTA; TEIXEIRA, 1988, 1987). The maximum dimension of the elements generated was 2 mm (VARMA; KANNAN, 2006) refined according to a geometrical expansion factor of 1.3 (VARMA; KANAN, 2006, 2005). The grid was formed by 102,678 elements in the model in conventional orientation, 103,180 in inverted and 252,164 in lying down (horizontal) orientation.

The following considerations and the initial and boundary conditions were used, which are frequently used in literature (KANNAN; SANDAKA, 2008; VARMA; KANNAN, 2006, 2005; GHANI, 2006; GHANI; FARID, 2006; CHEN; HUANG; GHANI, 2005; FARID; GHANI, 2004; DENYS; PIETERS;

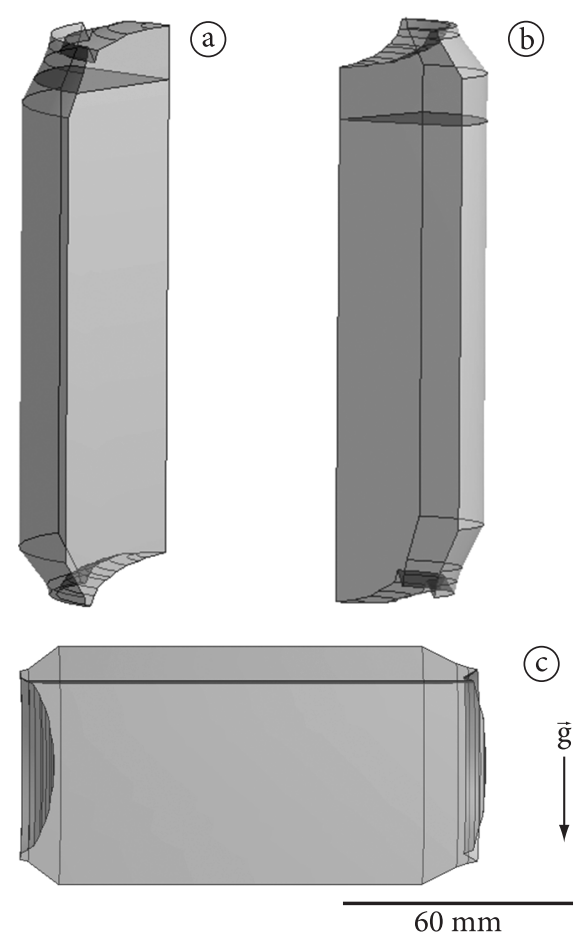

Figure 1. Aluminum can containing product and headspace in the a) conventional, b) inverted, and c) horizontal orientations. 
DEWETTINK, 2004; GHANI; FARID; CHEN, 2001a, 2001b, 2001c; GHANI et al., 2001a, 2001b, 1999a, 1999b; KUMAR; BHATTACHARYA, 1991; KUMAR; BHATTACHARYA; BLAYLOCK, 1990):

- Uniform initial temperature $\left(25^{\circ} \mathrm{C}\right)$;

- Velocity of the fluid convection currents on the $\mathrm{x}, \mathrm{y}$, and $\mathrm{z}$ axis are null at $\mathrm{t}=0$;

- Velocity of fluid convection currents on the packaging walls are null (no slip condition);

- Viscous dissipation and internal generation of energy are negligible; and

- Constant physical properties, except for density in the Boussinesq Approximation (relation between fluid density and its temperature).

As the boundary condition, packaging heating was considered to be uniform, with the mean temperature at $60{ }^{\circ} \mathrm{C}$ and $h$ determined in a preliminary study for a well stirred hot water bath (AUGUSTO; PINHEIRO; CRISTIANINI, 2008), as used by Brandon et al. (1984) and Brandon, Pelton and Staack (1982). The time step used was 1.0 second.

\subsection{Evaluations}

The chemical and biochemical reactions (such as the microbial inactivation) involved in the thermal processes of food have an exponential relation with the temperature. Thus, even small differences in the temperature of the thermal exchange medium can be significant along the process. When related to microbial inactivation, resulting in different final loads, they may be critical when considering the exponential nature of the microbial growth (AUGUSTO; SANTANA; CRISTIANINI, 2008).

In this case, the importance of the evaluation and comparison of processes are confirmed, not only through thermal profiles, but especially through the resulting sterilization values $(F)$. In the case of liquid foods, in which there is a mixture of product regions, final microbial count will be the mean value of the various portions. In this case, the process can be dimensioned and evaluated through the mass average sterilization value (Fm) (Equation 1; calculated with $\mathrm{T}_{\text {ref }}$ of $60^{\circ} \mathrm{C}$, according to HORN et al., 1997):

$F m=\frac{1}{V} \int_{V_{0}}^{V_{V_{0}}} \int_{t_{f}}^{t_{f}} 10 \frac{T(t, V)-T_{r e f}}{z} d t d V$

The efficiency in the thermal process was compared among the models, oriented in conventional, inverted or horizontal manner, through the Fm. The temperature and velocity profiles were also evaluated in the three models, as well the SHZ.

\section{Results and discussions}

Figures 2, 3, and 4 show thermal and velocity profiles (through streamlines) for the conventional, inverted and horizontal orientations, respectively, after 60, 100, 200, 300, and 1,300 seconds of process.

The temperature and velocity profiles were in accordance with those described in the literature on heating different products in cans and bottles, pasteurization of water in bottles (HORN et al., 1997; BRANDON et al., 1984; ENGELMAN; SANI, 1983; BRANDON; HULING; STAACK, 1983; BRANDON; PELTON; STAACK, 1982); sterilization of water in cylindrical cans (CHEN; HUANG; GHANI, 2005; GHANI et al., 1999a; DATTA; TEIXEIRA, 1988, 1987); pasteurization of water in cylindrical cans (BRANDON et al., 1984); sterilization of CMC suspension in cylindrical cans (KANNAN; SANDAKA, 2008; VARMA; KANNAN, 2006, 2005; CHEN; HUANG; GHANI, GHANI et al., 1999a, 1999b; KUMAR; BHATTACHARYA, 1991; KUMAR; BHATTACHARYA; BLAYLOCK, 1990); or sterilization of other model foods in cylindrical cans (GHANI; FARID; CHEN, 2002a; GHANI et al., 2001b).
Temperature

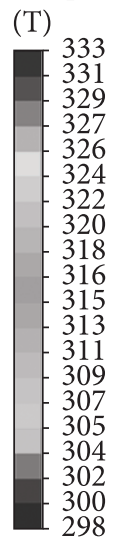

[K]

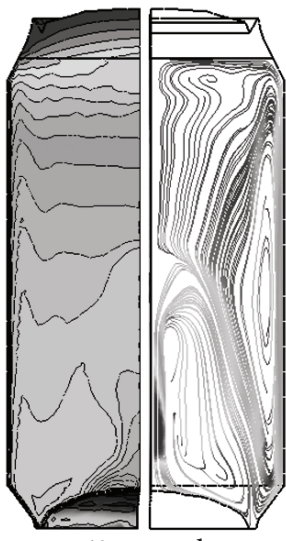

60 seconds

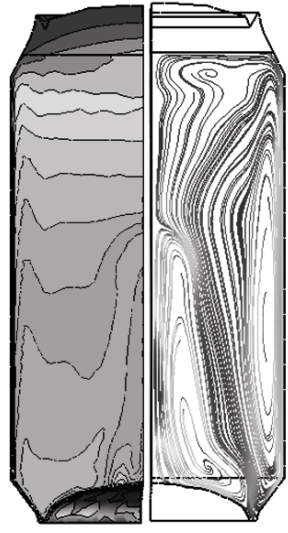

100 seconds

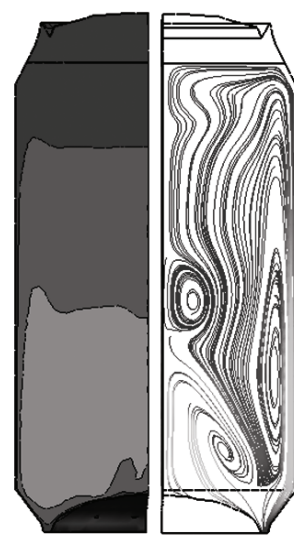

200 seconds

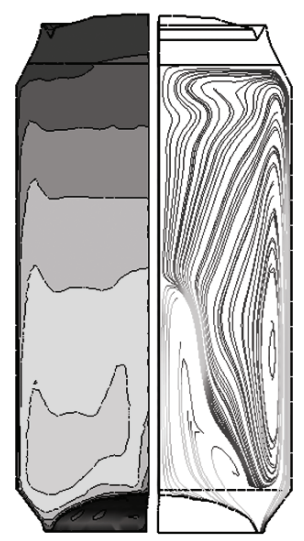

300 seconds

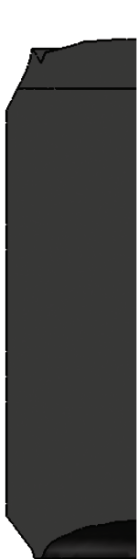

1300 seconds
Velocity

(v)

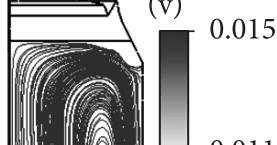

0.011

0.007

0.004

0.000

$[\mathrm{m} / \mathrm{s}]$

Figure 2. Thermal profiles and streamlines for water velocity while heating $\left(60{ }^{\circ} \mathrm{C} / 1,300\right.$ seconds) in commercial can at $60,100,200,300$, and 1,300 seconds: conventional orientation. 
Temperature

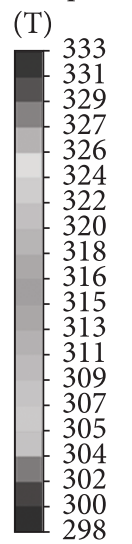

[K]

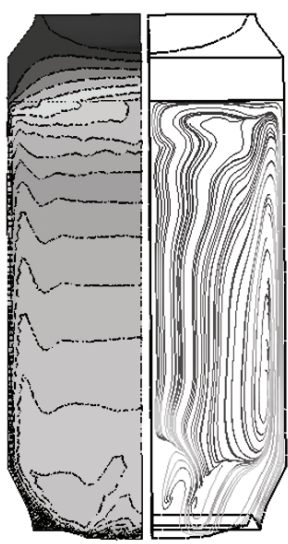

60 seconds

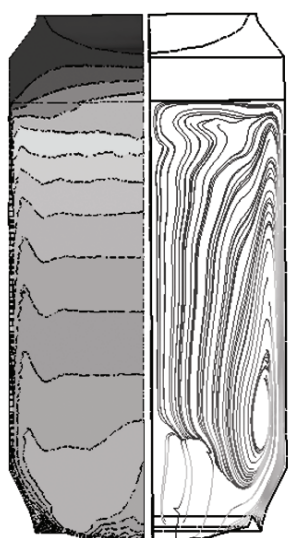

100 seconds

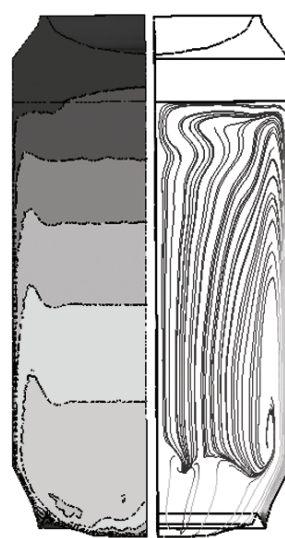

200 seconds

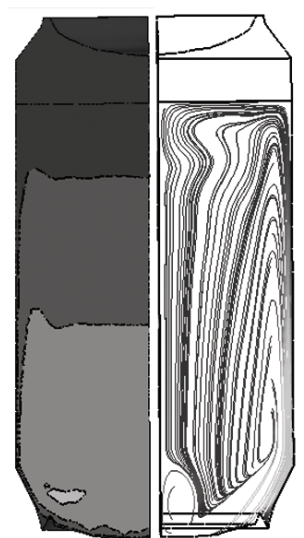

300 seconds

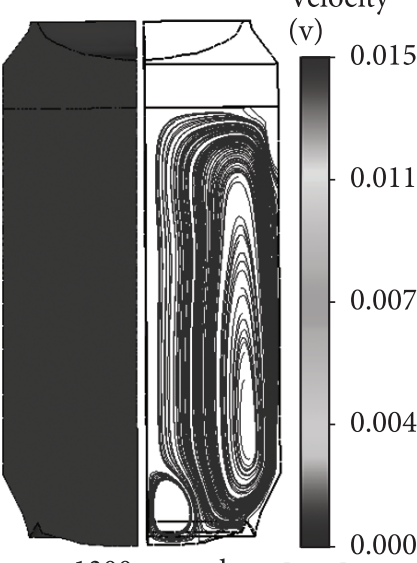

1300 seconds $[\mathrm{m} / \mathrm{s}]$
Velocity

Figure 3. Thermal profiles and streamlines for water velocity while heating $\left(60^{\circ} \mathrm{C} / 1,300\right.$ seconds) in commercial can at 60 , $100,200,300$, and 1,300 seconds: inverted orientation.

The Grashof Number (Gr - Equation 2) relates the fluid flow regime in natural convection (FARID; GHANI, 2004) the same way the Reynolds Number performs it with forced convection. The Gr calculated for the processes in question is in the order of $10^{7}-10^{8}$. According to Ghani et al. (1999a) and Farid and Ghani (2004), at such levels one can adopt the consideration of laminar flow, as done in the present paper.

$$
G r=\frac{(\text { buoyancy_forces })(\text { inertia } \text { forces })}{\left(\text { viscous }_{-} \text {forces }\right)^{2}}=\frac{g \cdot \beta \cdot\left(T-T_{\infty}\right) \cdot x^{3} \cdot \rho^{2}}{\mu^{2}}
$$

In the beginning of the process, the heating of the extremities leads to a large temperature gradient in the fluid and, consequently, density gradient, resulting in fluid movement in random distribution and characteristics of flows, as described by Ghani et al. (1999a), heating water and Carboxy-Methyl-Cellulose (CMC) suspension in cylindrical cans, Datta and Teixeira (1988, 1987), heating water in cylindrical cans, and Brandon et al. (1984) and Brandon, Pelton and Staack (1982), heating water in bottles. During that time, there is the presence and disintegration of various Benard Cells, circular currents formed due to the meeting of two or more currents. As the heating of the can is performed uniformly through its base, top, and side, the heating currents through these regions meet in determined points, forming the Benard Cells. If heating is continued, the currents tend to stabilize in a characteristic profile.

In the case of cans in the vertical position, both in the conventional and in the inverted orientation, one observes two main flows. A larger ascending flow in the extremities and descending in the center of the can and a smaller flow, a Benard Cell located in the base and in the symmetry axis of the can, in the opposed direction to the first (behavior that can be seen in 1,300 seconds Figures). This behavior is characteristic by uniformly heated fluids in recipients (GHANI et al., 1999a), and it was well described by Chen (2006) and Chen, Huang and Ghani (2005). The temperature profiles point towards a transient SHZ in contrast with the cold spot, characteristic of conductive products heating, and which, when becoming stable is positioned close to the base of the can, at about 10 to $20 \%$ of the liquid height. These results agree with those observed by various authors through experiments with CFD, and explained by Chen, Huang and Ghani (2005); or experimental studies such as the research by Zechman and Pflug (1989) and Brandon, Pelton and Staack (1982).

For the can in the horizontal position (Figure 4), one observes a similar profile in the planes adopted along the main axis, but with the final formation of only one flow. The curvature of the packaging side wall facilitated the formation of a single flow presenting more uniform characteristics than those in the vertical orientations. Since it does not present locations with meeting fluid currents of different heating, one observes a smaller number of Benard Cells. SHZ is stabilized in the lower part of the can, in a region between 5 and $10 \%$ of the liquid height (diameter of the can).

Comparison among the efficiencies in the thermal treatment of different packaging or conditions cannot be made through observation of their thermal histories or temperature profiles only. This approach does not consider the exponential relation of the reactions which occur in the food due to the temperature, where even small differences in temperature can be significant along the process. The most adequate means to evaluate such efficiencies is through the sterilization values $(\mathrm{F})$, calculated at the cold spot (Fp) for conductive foods or mass average sterilization value (Fm - Equation 1) for convective foods. However, this approach is rarely adopted, as can be observed in studies on can orientation and geometry comparison (VARMA; KANNAN, 2006, 2005; GHANI; FARID; CHEN, 2002a; BRANDON et al., 1984).

Figure 5 shows the values of Fm in PUs for the three orientations evaluated indicating that there are no differences among them. Unlike to the sterilization of consistent liquid foods (CMC suspension) in conical cans (VARMA; KANNAN, 2006, 2005), orientation of the packaging did not result in improvement of the process. This difference arises from the lesser consistency of the fluid, whose convection currents make the process more homogeneous. 


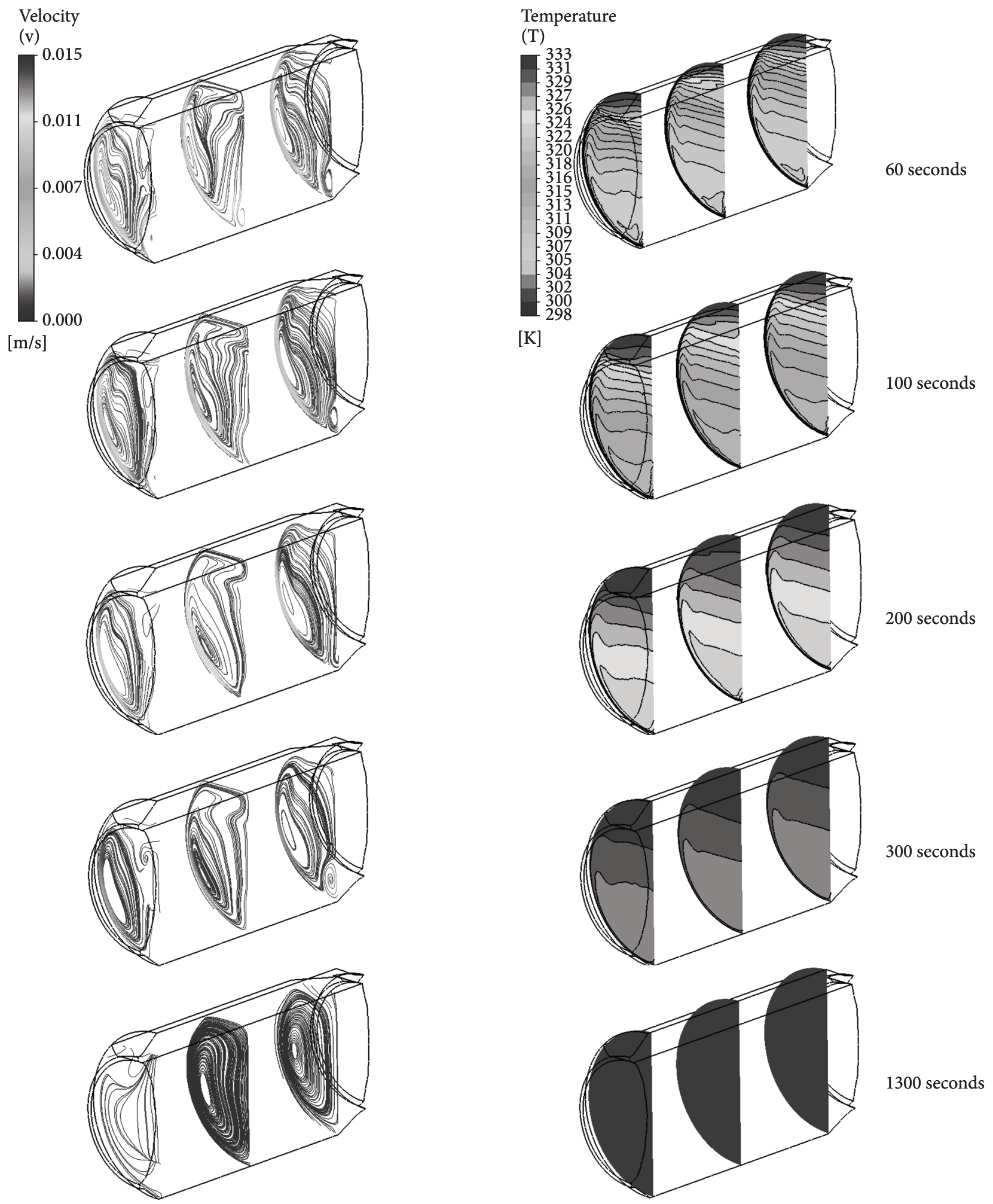

Figure 4. Streamlines for water velocity and thermal profiles in heating $\left(60^{\circ} \mathrm{C} / 1,300\right.$ seconds) in commercial can at $60,100,200,300$, and 1,300 seconds: horizontal orientation (planes at 10,50 , and $90 \%$ of the major can axis). 


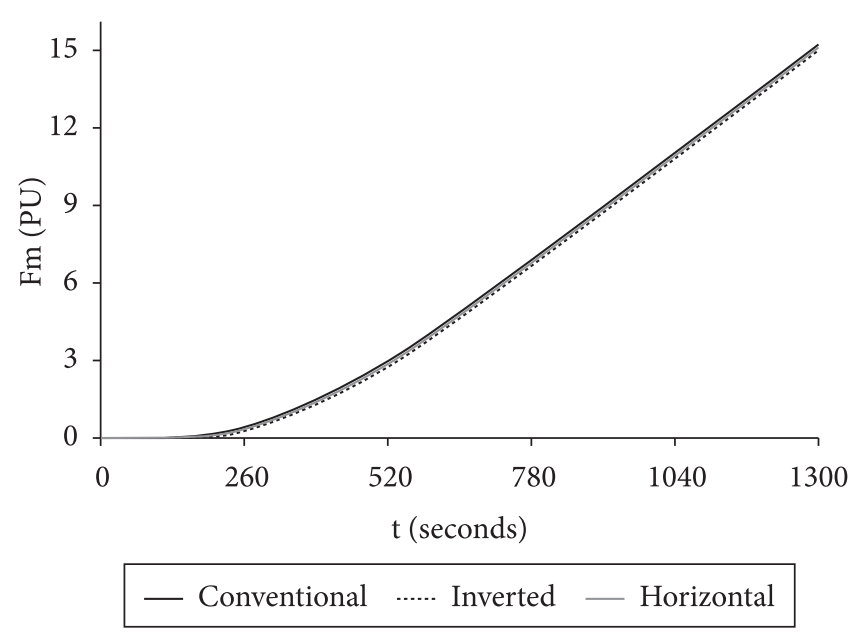

Figure 5. Comparison of efficiency in thermal process $\left(60{ }^{\circ} \mathrm{C} /\right.$ 1,300 seconds) of water in commercial aluminum can through the value of Fm, for conventional, inverted, and horizontal orientations.

\section{Conclusions}

The results obtained demonstrate the potential of using Computational Fluid-Dynamics (CFD) to evaluate thermal processes of liquid foods, such as beer pasteurization. One concludes that packaging orientation in the pasteurization of beers in cans does not alter the efficiency of the process.

\section{Nomenclature}

F: sterilization value;

Fm: mass average sterilization value;

g: gravitational acceleration;

Gr: Grashof Number;

h: convective heat transfer coefficient;

SHZ: slowest heating zone ;

T: temperature;

$\mathrm{T}_{\text {ref }}$ reference temperature;

$\mathrm{T}_{\infty:}$ temperature of the heating medium;

t: time;

PU: pasteurization units;

V: volume;

$\mathrm{x}$ : characteristic length (height, in the case of can in vertical position; diameter, when horizontal);

z: thermal coefficient;

$\beta$ : thermal expansion coefficient;

$\mu$ : viscosity;

$\rho:$ density.

\section{Acknowledgements}

The authors are grateful for the financial support provided by the São Paulo Research Foundation- FAPESP - project \# 2007/04121-6, and present their tribute to Nicolas Appert in celebration of 200 years of Appertization.

\section{References}

AUGUSTO, P. E. D.; SANTANA, F. F.; CRISTIANINI, M. Utilização de modelagem matemática para avaliação dos efeitos da temperatura de processos e das propriedades térmicas na esterilização de alimentos. Brazilian Journal of Food Technology, v. 11, n. 2, p. 159-168, 2008.

AUGUSTO, P. E. D.; PINHEIRO, T. F.; CRISTIANINI, M. Utilização de fluidodinâmica computacional (CFD) na avaliação do efeito da geometria e orientação de garrafas no tratamento térmico de bebidas. In: BRAZILIAN MEETING ON CHEMISTRY OF FOOD AND BEVERAGES (BMCFB), 7., 2008. Annals..., 2008.

BLANPAIN-AVET, P; FILLAUDEAU, L.; LALANDE, M. Investigation of mechanisms governing membrane fouling and protein rejection in the sterile micro-filtration of beer with an organic membrane. Food and Bio-products Processing, v. 77, n. 2, p. 75-89, 1999.

BRANDON, H. et al. Time-dependent modeling of in-package pasteurization. MBAA Technical Quarterly, v. 21, n. 4, p. 153-159, 1984.

BRANDON, H.; HULING, J.; STAACK, G. Computer simulation of pasteurizer performance. MBAA Technical Quarterly, v. 20, n. 1, p. 39-46, 1983.

BRANDON, H.; PELTON, P.; STAACK, G. State-of-the-art methodology for evaluating pasteurizer heating and cooling processes. MBAA Technical Quarterly, v. 19, n. 1, p. 34-40, 1982.

BUZRUL, S. A suitable model of microbial survival curves for beer pasteurization. LWT - Food Science and Technology, v. 40, n. 8, p. 1330-1336, 2007.

BUZRUL, S.; ALPAS, H.; BOZOGLU, F. Effect of high hydrostatic pressure on quality parameters of lager beer. Journal of the Science of Food and Agriculture, v. 85, n. 10, p. 1672-1676, $2005 \mathrm{a}$.

BUZRUL, S.; ALPAS, H.; BOZOGLU, F. Effect of high hydrostatic pressure on shelf life of lager beer. European Food Research and Technology, v. 220, n. 5-6, p. 615-618, 2005 b.

CHEN, X. D. Modeling thermal processing using computational fluid dynamics (CFD). In: SUN, D. W. Thermal food processing: new technologies and quality issues. Boca Raton: CRC, 2006.

CHEN, X. D.; HUANG, H. J.; GHANI, A. G. A. Thermal sterilization of liquid foods in a sealed container - developing simple correlations to account for natural convection. International Journal of Food Engineering, v. 1, n. 1, art. 5, 2005.

CRISTIANINI, M.; MASSAGUER, P. R. Thermal process evaluation of retortable pouches filled with conduction heated food. Journal of Food Process Engineering, v. 25, n. 5, p. 395-405, 2002.

DAGAN, G. F.; BALABAN, M. O. Pasteurization of beer by a continuous dense-phase $\mathrm{CO}_{2}$ system. Journal of Food Science, v. 71, n. 3, p. 164-169, 2006.

DATTA, A. K.; TEIXEIRA, A. A. Numerical modeling of natural convection heating in canned liquid foods. Transactions of the ASAE, v. 30, n. 5, p. 1542-1551, 1987.

DATTA, A. K.; TEIXEIRA, A. A. Numerically predicted transient temperature and velocity profiles during natural convection heating of canned liquid foods. Journal of Food Science, v. 53, n. 1, p. 191-195, 1988. 
DENYS, S.; PIETERS, J. G.; DEWETTINK, K. Computational fluid dynamics analysis of combined conductive and convective heat transfer in model eggs. Journal of Food Engineering, v. 63, n. 3, p. 281-290, 2004.

DILAY, E. et al. Modeling, simulation and optimization of a beer pasteurization tunnel. Journal of Food Engineering, v. 77, n. 3, p. 500-513, 2006.

ENGELMAN, M. S.; SANI, R. L. Finite-element simulation of an inpackage pasteurization process. Numerical Heat Transfer, v. 6, n.1, p. 41-54, 1983.

FARID, M.; GHANI, A. G. A. A new computational technique for the estimation of sterilization time in canned food. Chemical Engineering and Processing, v. 43, n. 4, p. 523-531, 2004.

FILLAUDEAU, L.; CARRÈRE, H. Yeast cells, beer composition and mean pore diameter impacts on fouling and retention during cross-flow filtration of beer with ceramic membranes. Journal of Membrane Science, v. 196, n. 1, p. 39-57, 2002.

FRANCHI, M. A. Estabilização microbiológica de cerveja por alta pressão dinâmica e tratamento combinado utilizando bioprotetores. Tese (Doutorado em Tecnologia de Alimentos)Faculdade de Engenharia de Alimentos, Universidade Estadual de Campinas, Campinas, 2007. Available from: <https://www.fea. unicamp.br/alimentarium/see_document.php?did=364>. Access in: 26 July 2008.

GHANI, A. G. A. A computer simulation of heating and cooling liquid food during sterilization process using computational fluid dynamics. Association for Computing Machinery New Zealand Bulletin, v. 2, n. 3, 2006. Available from: <http://www.acm.org/ chapters /acm_nz/bulletin/vol2/issue3/articles/v2i3id01.pdf $>$. Access in: 19 Jan. 2007.

GHANI, A. G. A. et al. Numerical simulation of natural convection heating of canned food by computational fluid dynamics. Journal of Food Engineering, v. 41, n. 1, p. 55-64, 1999a.

GHANI, A. G. A. et al. An investigation of deactivation of bacteria in a canned liquid food during sterilization using computational fluid dynamics (CFD). Journal of Food Engineering, v. 42, n. 4, p. 207-214, 1999b.

GHANI, A. G. A. et al. Thermal sterilization of canned food in a 3-D pouch using computational fluid dynamics. Journal of Food Engineering, v. 48, n. 2, p. 147-156, 2001a.

GHANI, A. G. A. et al. Numerical simulation of biochemical changes in a viscous liquid canned food during sterilization using computational fluid dynamics. Food Australia, v. 53, n. 1-2, p. 48-53, 2001b.

GHANI, A. G. A.; FARID, M. M. Using computational fluid dynamics to analyze the thermal sterilization of solid-liquid food mixture in cans. Innovative Food Science \& Emerging Technologies, v. 7, n. 1-2, p. 55-61, 2006.

GHANI, A. G. A.; FARID, M. M.; CHEN, X. D. Numerical simulation of transient temperature and velocity profiles in a horizontal can during sterilization using computational fluid dynamics. Journal of Food Engineering, v. 51, n. 1, p. 77-83, 2002a.

GHANI, A. G. A.; FARID, M. M.; CHEN, X. D. Theoretical and experimental investigation of the thermal inactivation of Bacillus stearothermophilus in food pouches. Journal of Food Engineering, v. 51, v. 3, p. 221-228, 2002 b.

GHANI, A. G. A.; FARID, M. M.; CHEN, X. D. Theoretical and experimental investigation of the thermal destruction of vitamin $\mathrm{C}$ in food pouches. Computers and Electronics in Agriculture, v. 34, n. 1-3, p. 129-143, 2002c.

HORN, C. S. et al. Modeling and simulation of pasteurization and staling effects during tunnel pasteurization of bottled beer. Food and Bioproducts Processing, v. 75, n. 1, p. 23-33, 1997.
KANNAN, A.; SANDAKA P. C. G. Heat transfer analysis of canned food sterilization in a still retort. Journal of Food Engineering, v. 88 , n. 2, p. 213-228; 2008.

KUMAR, A.; BHATTACHARYA, M. Transient temperature and velocity profiles in a canned non-Newtonian liquid food during sterilization in a still-cook retort. International Journal of Heat and Mass Transfer, v. 34, n. 4-5, p. 1083-1096, 1991.

KUMAR, A.; BHATTACHARYA, M.; BLAYLOCK, J. Numerical simulation of natural convection heating of canned thick viscous liquid food products. Journal of Food Science, v. 55, n. 5, p. 1403-1411, 1990.

KUMAR, A.; DILBER, I. Fluid flow and its modeling using computational fluid dynamics. In: SABLANI, S. S.; DATTA, A. K.; SHAFIURRAHMAN, M. (Eds.). Handbook of food bioprocess modeling techniques. Boca Raton: CRC, 2007.

NORTON, T.; SUN, D. W. Computational fluid dynamics (CFD) - an effective and efficient design and analysis tool for the food industry: a review. Trends in Food Science and Technology, v. 17, n. 11, p. 600-20, 2006.

PINHO, C.; CRISTIANINI, M. Three-dimensional mathematical modeling of microbiological destruction of Bacillusstearothermophilus in conductive baby food packed in glass container. International Journal of Food Engineering, v.1, n. 2, p. 1-8, 2005.

REVERON, I. M.; BARREIRO, J. A.; SANDOVAL, A. J. Thermal resistance of Saccharomyces cerevisiae in Pilsen beer. Journal of the Institute of Brewing, v. 109, n. 2, p. 120-122, 2003.

RIVEROL, C.; NAPOLITANO, V. Estimation of the overall heat transfer coefficient in a tubular heat exchanger under fouling using neural networks: application in a flash pasteurizer. International Communications in Heat and Mass Transfer, v. 29, n. 4, p. 453-457, 2002.

SANTANA, F. F. Modelamento matemático de alimentos com particulados pelo método dos elementos finitos. Dissertação (Mestrado em Tecnologia de Alimentos)-Faculdade de Engenharia de Alimentos, Universidade Estadual de Campinas, Campinas, 2007.

SCOTT, G.; RICHARDSON, P. The application of computational fluid dynamics on food industry. Trends in Food Science and Technology, v. 8, n. 4, p. 119-24, 1997.

TRIBST, A. A. L.; FRANCHI, M. A.; CRISTIANINI, M. Ultra-high pressure homogenization treatment combined with lysozyme for controlling Lactobacillus brevis contamination in model system. Innovative Food Science \& Emerging Technologies, v. 9, n. 3, p. 265-271, 2008.

VARGA, S.; OLIVEIRA, J. C.; OLIVEIRA, F. A. R. Influence of the variability of processing factors on the F-value distribution in batch retorts. Journal of Food Engineering, v. 44, p. 155-161, 2000.

VARMA, M. N.; KANNAN, A. CFD studies on natural convective heating of canned food in conical and cylindrical containers. Journal of Food Engineering, v. 77, n. 4, p. 1024-1023, 2006.

VARMA, M. N.; KANNAN, A. Enhanced food sterilization through inclination of the container walls and geometry modifications. International Journal of Heat and Mass Transfer, v. 48, n. 18, p. 3753-3762, 2005.

XIA, B.; SUN, D. W. Applications of computational fluid dynamics (CFD) in the food industry: a review. Computers and Electronics in Agriculture, v. 34, n. 1-3, p. 5-24, 2002.

ZECHMAN, L. G.; PFLUG, I. J. Location of the slowest heating zone for natural-convection-heating fluids in metal containers. Journal of Food Science, v. 54, n. 1, p. 205-209, 226, 1989. 